\title{
Jurist-Diction
}

Volume 1 No. 2, November 2018

Article history: Submitted 1 October 2018; Accepted 8 October 2018; Available online 1 November 2018

\section{PERLINDUNGAN PELAUT INDONESIA DI LUAR NEGERI MELALUI RATIFIKASI MARITIME LABOUR CONVENTION, 2006}

\author{
Nina Farah Adela \\ nina.farah.adela-2014@fh.unair.ac.id \\ Universitas Airlangga
}

\begin{abstract}
Seafarers is an occupation that entails great responsibility and high risks, such as ship crashing and sinking. It is necessary to establish more stringent set of rules and regulations on the qualifications on becoming a seafarer and to provide them with a more comprehensive legal protection. The provisions of the existing national regulations are considered imbalanced, resulting in the situation of legal uncertainty. Therefore, the protection of Indonesian seafarers at the time being is still low and not in accordance with international standards. This is evident in a number of problems experienced by the seafarers, such as employment frauds, unpaid wages, fraudulent documents and slavery. Due to the aforementioned reasons, the Indonesian government ratified the Maritime Labor Convention, 2006 on October 6, 2016 through Law of the Republic of Indonesia Number 15 Year 2016 concerning the Ratification of the Maritime Labor Convention, 2006. This research is a legal research prepared using statute and conceptual approach. MLC 2006 will be compared to the provisions of current existing national law, namely, Law of the Republic of Indonesia Number 17 Year 2008 concerning Shipping and Government Regulation of the Republic of Indonesia Number 7 Year 2000 concerning Maritime Affairs. In the initial discussion, the basic rights obtained by seafarers during their work on board and the protection provided before, during and at the return of seafarers are described. From this legal research, it is known that the MLC 2006 paid more attention to the basic rights of seafarers, such as wages, working hours, provision of latest facilities and the right to repatriation. MLC 2006 also contributed more to the legal protection of Indonesian seafarers. As a State party that ratified MLC 2006, Indonesia has a new obligation in terms of following the reimbursement system and is a subject to the International Convention of Arrest of Ships 1999.
\end{abstract}

Keywords: Maritime Labor Convention 2006; Seafarers; Seafarers Rights; Legal Protection.

\begin{abstract}
Abstrak
Pelaut merupakan salah satu pekerjaan yang memiliki tanggung jawab besar dan beresiko tinggi seperti, kecelakaan kapal dan tenggelam. Untuk mencegah resiko, diperlukan kualifikasi pekerja sebagai pelaut yang lebih ketat dan pemberian perlindungan hukum bagi pelaut yang diatur secara komprehensif. Ketentuan Perundang-undangan nasional dinilai belum seimbang dan menimbulkan ketidakpastian hukum. Oleh karena itu, perlindungan pelaut Indonesia masih rendah dan belum sesuai standar internasional. Hal ini dibuktikan dengan berbagai permasalahan yang telah dialami pelaut antara lain, penipuan job fiktif, upah tidak dibayar, dokumen palsu hingga perbudakan. Dengan demikian, pemerintah Indonesia meratifikasi Maritime Labour Convention 2006 (MLC 2006) pada tanggal 6 Oktober 2016 melalui Undang-Undang Nomor 15 Tahun 2016 tentang Pengesahan Maritime Labour Convention, 2006. Penelitian ini merupakan penelitian hukum yang disusun dengan menggunakan pendekatan peraturan perundang-undangan dan pendekatan konseptual. MLC 2006 akan dikaji menggunakan perbandingan dengan ketentuan hukum nasional yang sudah ada di Indonesia yaitu, Undang-Undang Nomor 17 Tahun 2008 tentang Pelayaran dan Peraturan Pemerintah Nomor 7 Tahun 2000 tentang Kepelautan. Pada pembahasan awal, diuraikan hak-hak dasar yang diperoleh pelaut selama bekerja di atas kapal dan perlindungan yang diberikan sebelum, selama, dan saat pemulangan pelaut. Dari penelitian hukum ini, diketahui bahwa MLC 2006 memberikan
\end{abstract}


perhatian lebih terhadap hak-hak dasar pelaut misalnya, upah, jam kerja, penyediaan fasilitas terbaru dan hak repatriasi pelaut. MLC 2006 juga memberikan kontribusi lebih bagi perlindunugan hukum pelaut Indonesia. Sebagai negara anggota yang telah meratifikasi MLC 2006, Indonesia memiliki kewajiban baru dalam hal mengikuti sistem reimburshment (pengembalian) dan tunduk pada International Convention of Arrest of Ships 1999.

Kata Kunci: Maritime Labour Convention 2006; Pelaut; Hak-Hak Dasar Pelaut; Perlindungan Hukum.

\section{Pendahuluan}

Pada tahun 2015, dikeluarkan data penempatan TKI yang dikelola Badan Nasional Penempatan dan Perlindungan Tenaga Kerja Indonesia (BNP2TKI) menyatakan bahwa Indonesia merupakan negara penyumbang pekerja maritim terbesar ketiga di dunia hingga saat ini, dengan jumlah pelaut sekitar 254.186 orang yang bekerja di kapal asing. ${ }^{1}$ Peningkatan pekerja pelaut tidak terlepas dari permasalahan yang terjadi. Berdasarkan data terbaru dari Direktorat Perlindungan Warga Negara Indonesia dan Badan Hukum Indonesia (Dit. PWNI BHI), dari tahun 2012 - 2015, sekitar 221 pelaut Indonesia terindikasi menjadi korban tindak pidana perdagangan orang (TPPO). ${ }^{2}$ Pada tahun 2017, Pergerakan Pelaut Indonesia ${ }^{3}$ (selanjunya disingkat PPI) sebagai Serikat Pekerja sektor pelaut, sedikitnya menerima 200 pengaduan kasus pelaut yang masuk, yaitu upah tidak dibayar, tertipu job fiktif, penelantaran di luar negeri. ${ }^{4}$

Instrumen hukum nasional yang ada belum mencakup secara komprehensif terhadap hak pelaut seperti Undang-Undang Republik Indonesia Nomor 13 Tahun 2003 tentang Ketenagakerjaan dan Undang-Undang Nomor 17 Tahun 2008 tentang Pelayaran serta peraturan dibawahnya yaitu Peraturan Pemerintah Nomor 7 Tahun 2000 tentang Kepelautan. Jika dibandingkan dengan Maritime Labour Convention, 2006 (MLC 2006), mengatur lebih luas terhadap hak-hak yang didapat pelaut dan penegakan hukumnya, sebagai contoh ketentuan tentang hak repatriasi dan standar

1 Pusat P2K OI - BPPK Kementerian Luar Negeri Republik Indonesia, Strategi Perlindungan dan Penanganan Kasus Anak Buah Kapal (SEAFARER) Sektor Perikanan Indonesia yang Bekerja di Luar Negeri, hasil penelitian.[1].

2 Ibid.

3 Serikat ini didirikan berdasarkan Surat Keputusan (SK) Nomor 87 Menteri Hukum dan Hak Asasi Manusia dan Tanda Bukti Pencatatan (TBP) PPI dari Dinas Ketenagakerjaan.

4 Tak Pernah Berhenti Perjuangkan Nasib Pelaut, PPI Rilis Catatan Akhir Tahun 2017, http://www.maritimenews.com, dikunjungi pada tanggal 27 Maret 2018. 
akomodasi dan fasilitas rekreasi di kapal.

MLC 2006 bertujuan untuk memastikan hak-hak dasar pelaut di seluruh dunia yang meliputi upah, syarat kerja termasuk waktu kerja dan waktu istirahat, perawatan medik, jaminan kesehatan, perekrutan dan penempatan, pelatihan dan pengawasan untuk dilindungi dan memberikan standar pedoman bagi pelaut. Secara singkat, Konvensi ini memuat standardisasi minimum bagi pelaut, pengaturan jaminan atas keamanan dan kenyamanan termasuk lingkungan kerja yang layak. Oleh karena itu, Indonesia meratifikasi MLC 2006 melalui Undang-Undang Nomor 15 Tahun 2016 pada tanggal 6 Oktober 2016. Ratifikasi MLC 2006 membawa peranan penting bagi Indonesia untuk dapat meningkatkan perlindungan dan pemenuhan hak-hak dari pelaut Indonesia sejalan dengan prinsip hak asasi manusia.

Penelitian ini merupakan penelitian hukum yang disusun dengan menggunakan pendekata peraturan perundang-undangan dan pendekatan konseptual. Isu hukum yang diangkat dalam penelitian ini adalah pengaturan hak-hak dasar bekerja pelaut serta perlindungan hukum yang diberikan kepada pelaut sebelum lahirnya UndangUndang Nomor 15 Tahun 2016 dan menurut MLC 2016.

\section{Pengaturan Hak-Hak Dasar Bekerja Profesi Pelaut Dalam Perspektif Hukum Nasional dan Internasional}

Hak bekerja merupakan amanat konstitusi sebagaimana tercantum dalam Pasal 27 Undang-Undang Dasar 1945 yang secara tegas menyatakan, bahwa "tiap-tiap warga negara berhak atas pekerjaan dan penghidupan yang layak bagi kemanusiaan”. Ketentuan tersebut mengandung makna bahwa setiap warga negara berhak untuk mendapatkan pekerjaan sesuai keahlian dan keterampilan mereka, serta memperoleh imbalan untuk keperluan hidup yang layak. Hak bekerja termasuk inti dari pemenuhan hak asasi manusia.

Hak asasi manusia merupakan hak fundamental yang terdiri dari 3 (tiga) pokok, yaitu:
a. Hak untuk hidup;
b. Hak atas kebebasan; dan 
c. Hak untuk memiliki.

Bekerja merupakan tujuan dari pemenuhan kebutuhan untuk kondisi hidup yang layak. Hak bekerja juga dikaitkan dengan hak atas kebebasan seperti bebas dari perbudakan dan praktek-praktek serupa, bebas dari kerja paksa dan kerja wajib (sebagaimana dimaksud dalam Konvensi ILO Nomor 29 tentang Kerja Paksa, hak atas layanan kerja yang bebas yakni menyangkut hak terhadap akses informasi yang bebas dan pendampingan dan bantuan dari para pencari kerja untuk mendapatkan pekerjaan yang layak, hak untuk bekerja, hak untuk mendapatkan perlindungan hukum dalam pekerjaan, hak perlindungan terhadap pengangguran). ${ }^{5}$ Selanjutnya, hak untuk memiliki kesempatan yang sama dalam memperoleh pekerjaan.

Pemerintah dalam hal ini bertanggung jawab untuk melindungi hakhak individu maupun kelompok, hukum hak-hak dasar atas pekerjaan dapat ditemukan dalam peraturan perundang-undangan nasional dan internasional. Untuk memudahkan memahami substansi, pemetaan berikut secara rinci mengemukakan Pasal-Pasal dan penjelasan yang merujuk pada peraturan nasional dan internasional terkait hak-hak dasar bekerja pelaut.

\section{Dasar Hukum Hak Dasar Bekerja Pelaut Menurut Ketentuan Nasional Peraturan Pemerintah Nomor 7 Tahun 2000 tentang Kepelautan}

Pasal 18 secara jelas menyebutkan hak-hak pelaut yang dimuat dalam perjanjian kerja laut sekurang-kurangnya adalah hak untuk menerima gaji, upah, lembur, uang pengganti hari-hari libur, uang delegasi, biaya pengangkutan dan upah saat diakhirinya pengerjaan, pertanggungan untuk barang-barang milik pribadi yang dibawa serta kecelakaan pribadi serta perlengkapan untuk musim dingin untuk yang bekerja di wilayah dengan suhu 15 derajat Celsius atau kurang yang berupa pakaian dan peralatan musim dingin. Pelaut dalam PP ini pada Bagian Kelima juga memiliki hak atas akomodasi selama bekerja di atas kapal.

\footnotetext{
5 Sukmawati Mustari, Hak Atas Pekerjaan Dengan Upah Yang Seimbang, Supremasi Jurnal Fakultas Ilmu Sosial Universitas Negeri Makassar, Vol. XI, No. 2, 2016.[12].
} 


\section{Undang-Undang Nomor 17 Tahun 2008 tentang Pelayaran}

Pada Bagian Kelima mengenai kesejahteraan awak kapal dan kesehatan penumpang, Pasal 151 menyebutkan bahwa awak kapal berhak untuk mendapatkan kesejahteraan yang meliputi gaji; jam kerja dan jam istirahat; jaminan pemberangkatan ketempat tujuan dan pemulangan ketempat asal; kompensasi apabila kapal tidak dapat beroperasi karena mengalami kecelakaan; kesempatan mengembangkan karier; pemberian akomodasi, fasilitas rekreasi, makanan atau minuman; dan pemeliharaan dan perawatan kesehatan serta pemberian asuransi kecelakaan kerja. Hak-hak tersebut dinyatakan dalam perjanjian kerja laut.

\section{Peraturan Menteri Perhubungan Nomor 84 Tahun 2013 tentang Perekrutan dan Penempatan Awak Kapal}

Hak-hak yang didapat pelaut dalam peraturan menteri ini diatur pada Bagian Kedua tentang tanggung jawab yang harus dipenuhi oleh perusahaan keagenan awak kapal. Hal ini tertuang dalam ketentuan Pasal 15 bahwa perusahaan keagenan terhadap pelaut wajib menjamin hak-hak pelaut sesuai perjanjian kerja termasuk hak-hak lainnya di luar perjanjian itu, antara lain: menjamin proses perawatan medis dan pengobatan apabila pelaut cedera atau sakit, menyediakan bantuan hukum, mengurus dokumen kepelautan dan dokumen terkait lainnya, serta membantu pengiriman sebagian gaji.

\section{Peraturan Kepala Badan Nasional Penempatan dan Perlindungan Tenaga Kerja Indonesia Nomor PER-03/KA/I/2013 tentang Tata Cara Penempatan dan Perlindungan Tenaga Kerja Indonesia Pelaut Perikanan di Kapal Berbendara Asing}

Melihat kasus-kasus yang dihadapi oleh pelaut perikanan yang bekerja di luar negeri semakin marak dan beragam serta berkembang ke arah eksplotasi dan perdagangan manusia sehingga diperlukan pengaturan tentang perlindungan bagi para pelaut perikanan yang bekerja di kapal asing. Hal ini tentunya berkaitan dengan hak-hak yang harus didapatkan oleh pelaut perikanan. 
Bagian III angka 2 huruf i tentang perjanjian kerja laut wajib memuat syaratsyarat kerja tentang hak-hak pelaut diantaranya gaji, jam kerja, upah lembur, cuti, istirahat, bonus sesuai perhitungan, jaminan sosial, dan sebagainya. Pada huruf $\mathrm{k}$ dan 1 pelaut juga memiliki hak atas perawatan medis saat melakukan pekerjaan dan hak pemulangan.

\section{Peraturan Kepala Badan Nasional Penempatan dan Perlindungan Tenaga Kerja Indonesia Nomor PER-12/KA/IV/2013 tentang Tata Cara Perekrutan, Penempatan dan Perlindungan Pelaut di Kapal Berbendera Asing}

Pada angka 8 dalam peraturan ini, terhadap hak-hak yang dimiliki oleh pelaut wajib dimuat dalam perjanjian kerja laut yakni syarat-syarat kerja yang meliputi antara lain gaji, waktu kerja, waktu istirahat, cuti, lembur, upah lembur dan jaminan sosial. Setiap pelaut juga berhak menjadi anggota serikat pekerja pelaut sebagaimana tertulis dalam angka 12 huruf (a). Kemudian, pelaut memiliki hak atas pesangon apabila terjadi pemutusan hubungan kerja (Bagian IV tentang perlindungan pelaut angka 4) dan hak atas gaji dan biaya selama perawatan dan pengobatan apabila sakit atau cedera (angka 5).

\section{Undang-Undang Nomor 15 Tahun 2016 tentang Pengesahan Maritime Labour Convention, 2006 (Konvensi Ketenagakerjaan Maritime 2006)}

Pelaut memiliki hak-hak dasar antara lain upah, syarat kerja termasuk waktu kerja dan waktu istirahat, perawatan medik, jaminan kesehatan, perekrutan dan penempatan, pelatihan dan pengawasan. Upaya untuk memenuhi hak tersebut diperlukan pengaturan perlindungan pelaut. Dengan demikian, pemerintah Indonesia meratifikasi MLC 2006 melalui Undang-Undang Nomor 15 Tahun 2016.

Konvensi ini berlaku untuk semua kapal umum dan perseorangan, yang digunakan dalam kegiatan komersial selain dari kapal-kapal yang digunakan dalam penangkapan ikan atau melakukan kegiatan serupa dan kapal-kapal yang dibangun secara tradisional seperti kapal layar dan pinisi. Konvensi ini tidak berlaku pada 
kapal perang atau angkatan laut. ${ }^{6}$

\section{Ketentuan Internasional Tentang Hak-Hak Dasar Pelaut}

Convention ILO Maritime Labour Convention (MLC) 2006

Adapun ketentuan-ketentuan dalam MLC 2006 yang mengatur tentang prinsip dan hak-hak dasar bekerja yang dimiliki para pelaut, bahwa setiap negara anggota harus memastikan ketentuan peraturan perundang-undangan, dalam konteks Konvensi, menghormati hak-hak dasar terhadap:

a. Pasal 3 tentang hak-hak dasar atas kebebasan berserikat dan pengakuan; penghapusan kerja paksa, pekerja anak dan diskriminasi.

b. Pasal 4 tentang hak atas tempat kerja yang aman dan terlindungi, hak atas syarat-syarat kerja yang adil, hak atas kondisi kerja dan kehidupan yang layak, hak atas perlindungan kesehatan, perawatan medis, tingkat kesejahteraan dan bentuk perlindungan sosial.

\section{SOLAS Convention 1974 (The International Convention For The Safety Of Life} At Sea, 1974)

Ketentuan-ketentuan dalam SOLAS 1974 mengenai keamanan dan keselamatan kapal yang berkaitan dengan masalah administrasi kapal dengan mengidentifikasi beberapa persyaratan yang berlaku. Kemudian juga menjelaskan tentang tindakan khusus untuk meningkatkan keselamatan maritim pada BAB XI yang dapat memenuhi hak atas perlindungan.

MARPOL Convention (International Convention for the Prevention of Pollution from Ships)

MARPOL 1973 mengatur tentang perlindungan lingkungan laut dengan tindakan pencegahan dan penanggulangan apabila terjadi kecelakaan dan/atau pencemaran terhadap lingkungan maritim. Pentingnya diberlakukan konvensi

\footnotetext{
6 Pasal II angka 4, Konvensi Ketenagakerjaan Maritim, 2006.
} 
ini adalah untuk menjaga kelaiklautan kapal sehingga kapal tersebut tetap dapat beroperasi yang dalam hal ini berkaitan dengan pemenuhan hak atas bekerja.

\section{SCTW 1982 (International Convention on Standards of Training, Certification and Watchkeeping for Seafarers)}

SCTW 1978 tentang kompetensi kru kapal dengan menetapkan kualifikasi standar untuk kapten, perwira dan petugas jaga kapal niaga yang berlayar. Konvensi ini merupakan peraturan pertama yang menetapkan persyaratan dasar dalam latihan, sertifikasi dan dinas jaga pelaut dalam tingkat internasional. Hal ini berkaitan dengan pemenuhan hak pelaut atas syarat-syarat kerja yang adil dan hak atas pelatihan dan pengembangan diri.

\section{Pengaturan Perlindungan Pelaut Sebelum Ratifikasi Maritime Labour Convention 2006 dan Menurut Maritime Labour Convention 2006 \\ Perlindungan Pelaut sebelum Undang-Undang Nomor 15 Tahun 2016}

Upaya perlindungan terhadap pelaut Indonesia yang bekerja di kapal asing merupakan salah satu permasalahan penting saat ini. PPI menerima 200 pengaduan kasus pelaut termasuk yang bekerja di luar negeri. Kasus-kasus yang menimpa pelaut dimulai dari perbudakan, diskriminasi upah dengan pelaut warga negara asing padahal jabatannya sama hingga tidak dibayar, tertipu pekerjaan fiktif dan penelantaran pelaut. Melihat permasalahan tersebut, pemerintah Indonesia melakukan upaya preventif terhadap perlindungan pelaut telah dihasilkan peraturan perundang-undangan nasional yang secara khusus mengatur tentang pelaut, seperti Undang-Undang Pelayaran, Undang-Undang Kepelautan dan sebagainya.

\section{Undang-Undang Nomor 17 Tahun 2008 tentang Pelayaran}

Ketentuan Pasal 117 dalam undang-undang ini menekankan pada keselamatan dan keamanan angkutan perairan dengan pemenuhan syarat kelaiklautan kapal, yang didalamnya berkaitan dengan kesejahteraan awak kapal dan kesehatan penumpang. Kesejahteraan pelaut telah disebutkan dalam Pasal 151 pada bab sebelumnya. Akan 
tetapi, pengaturan kesejahteraan mengenai gaji dan tunjangan masih bersifat umum dan belum ada standar yang baku tentang besaran gaji atau upah minimum serta tunjangan kerja pelaut.

\section{Peraturan Pemerintah Nomor 7 Tahun 2000 tentang Kepelautan}

Pada PP ini menjelaskan secara rinci tentang hak-hak dan perlindungan yang diberikan pelaut yang diatur dalam BAB V Bagian Keempat tentang kesejahteraan awak kapal, antara lain: penetapan jam kerja dan perhitungan gaji pelaut termasuk saat hari libur (Pasal 21 dan 23). Apabila melakukan pekerjaan melebihi penetapan jam kerja maka, dihitung sebagai kerja lembur dan dibayar sebagai upah lembur yang dihitung dengan upah minimum: ${ }^{7}$

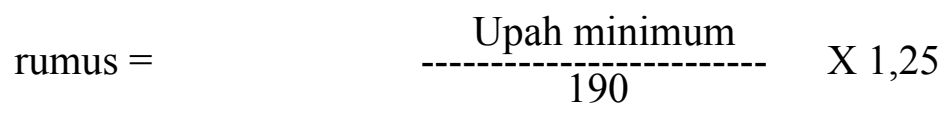

Selain itu, para pelaut mendapatkan hak atas pemberian makanan dan alatalat pelayanan (Pasal 25), hak atas biaya perawatan dan pengobatan apabila pelaut cacat akibat kecelakaan kerja (Pasal 28). Apabila kecelakaan tersebut menyebabkan matinya pelaut, maka biaya pemulangan dan penguburan jenazah serta santunan yang diperoleh pelaut ditanggung oleh pemilik kapal (Pasal 31). Selanjutnya, pelaut yang melakukan pemutusan hubungan kerja diberikan pesangon dan dikembalikan ke tempat asal (Pasal 26 dan 27).

\section{Undang-Undang Nomor 21 Tahun 2007 tentang Pemberantasan Tindak Pidana Perdagangan Orang}

Undang-Undang Pemberantasan TPPO mengatur perlindungan dasar kepada saksi dan korban praktik perdagangan orang sebagai aspek penting dalam penegakan hukum. Bertolak dari pengertian korban sebagaimana terdapat dalam Pasal 1 Ayat (3) dalam UU TPPO, maka siapa saja bisa menjadi korban. Artinya, baik perempuan,

\footnotetext{
7 Pasal 22 Peraturan Pemerintah Nomor 7 Tahun 2000 tentang Kepelautan.
} 
laki-laki, anak, maupun orang dewasa bisa saja menjadi korban dari suatu TPPO. ${ }^{8}$ Undang-Undang ini memberikan perhatian besar terhadap penderitaan korban dalam bentuk hak restitusi yang harus diberikan oleh pelaku TPPO sebagai ganti rugi, dan mengatur juga hak korban atas rehabilitasi medis dan sosial, pemulangan serta reintegrasi yang harus dilakukan oleh negara. ${ }^{9}$

\section{Peraturan Pemerintah Nomor 20 Tahun 2010 tentang Angkutan di Perairan}

PP ini sebagaimana dijelaskan pada Pasal 2 mengatur kegiatan angkutan laut, sungai dan danau, angkutan penyeberangan, angkutan di perairan untuk daerah masih tertinggal dan/atau terpencil, kegiatan jasa terkait dengan angkutan di perairan, perizinan, penarifan, kewajiban dan tanggung jawab pengangkut, pengangkutan barang khusus dan barang berbahaya, pemberdayaan industri angkutan di perairan, sistem informasi angkutan di perairan, dan sanksi administratif. Pada prinsipnya PP Angkutan Perairan menertibkan prosedur-prosedur yang diwajibkan kepada perusahaan kapal.

\section{Peraturan Menteri Perhubungan Nomor 84 Tahun 2013 tentang Perekrutan dan Penempatan Awak Kapal}

Pada Bagian Kedua mengatur tentang Tanggung Jawab perusahaan awak kapal terhadap pelaut yang ditempatkan atas isi perjanjian kerja untuk menjamin hak-hak pelaut sebagaimana diatur dalam ketentuan Pasal 14 - 20. Selain itu, pada Bab IV dan V memuat sanksi bagi perusahaan yang melanggar berupa sanksi administrasi dan penyelesaian perselisihan pelaut. Perusahaan keagenan awak kapal wajib memiliki dan menerapkan sistem manajemen mutu standar dan dilaporkan ke Direktur Jenderal Hubla untuk mendapatkan persetujuan sebagai pedoman perusahaan dalam menjalankan keagenan pelaut.

8 Paul SinlaEloe, Tindak Pidana Perdagangan Orang, Setara Press, Malang, 2017.[121].

9 Lihat penjelasan umum Undang-Undang Nomor 21 Tahun 2007 tentang Pemberantasan TPPO 


\section{Peraturan Menteri Kelautan dan Perikanan Nomor 35/PERMEN-KP/2015 tentang Sistem dan Sertifikasi HAM Usaha Perikanan}

Sebagai upaya perlindungan terhadap pekerja yang dimaksud dalam peraturan ini yakni awak kapal perikanan, nahkoda, dan ahli penangkapan ikan. Pengusaha perikanan memberikan pernyataan komitmen sebagaimana disebutkan dalam Pasal 5 ayat (2) untuk menghormati HAM para pihak yang terkena dampak pelanggaran HAM, menghormati hak untuk kondisi kerja yang adil dan layak, menerapkan perjanjian kerja laut dengan standar pengupahan layak, larangan kerja paksa, melaksanakan uji tuntas HAM, pemulihan HAM dan pelatihan sistem HAM kepada pekerja dan pelaut perikanan.

Peraturan Kepala Badan Nasional Penempatan dan Perlindungan Tenaga Kerja Indonesia Nomor : PER.13/KA/VII/2009 tentang Pendataan Pelaksana Penempatan Pelaut Indonesia di Luar Negeri

Ruang lingkup dalam pengaturan ini meliputi pendataan, prosedur, monitoring dan evaluasi. Sebagai pelaksana penempatan harus memenuhi syarat-syarat yang tertuang dalam huruf E ayat (2) untuk memperoleh Kartu Pendataan Pelaksana Penempatan Pelaut Indonesia. Kemudian, Pelaksana wajib mematuhi prosedur untuk penempatan dengan mengajukan permohonan surat ijin pengerahan, perjanjian penempatan, pengesahan perjanjian kerja laut, pemeriksaan kesehatan, pengurusan paspor, membayar asuransi, pembayaran DP3TKI (Dana Pembinaan Penempatan dan Perlindungan Tenaga Kerja Indonesia), permohonan KTKLN (Kartu Tenaga Kerja Luar Negeri), dan laporan kedatangan Pelaut Indonesia. Berkaitan dengan penertiban penempatan pelaut, maka dilakukan monitoring dan evaluasi untuk mengetahui dampak pendataan tersebut.

Peraturan Kepala Badan Nasional Penempatan dan Perlindungan Tenaga Kerja Indonesia Nomor : PER.03/KA/I/2013 tentang Tata Cara Penempatan dan Perlindungan Tenaga Kerja Indonesia Pelaut Perikanan di Kapal Berbendera Asing 
Perlindungan terhadap pelaut perikanan secara langsung diatur dalam ketentuan huruf $\mathrm{H}$ adalah pelaut perikanan wajib memiliki dokumen yang meliputi Pertama, perjanjian penempatan, sertifikat pemeriksaan kesehatan, paspor, buku pelaut, perjanjian kerja laut, asuransi di Indonesia, visa, dan KTKLN. Kedua, Pelaut perikanan juga wajib diasuransikan apabila terjadi risiko yang tidak diinginkan dan mendapat bantuan hukum apabila terjadi halangan. Ketiga, biaya pemulangan pelaut oleh Pengguna apabila karena berakhirnya perjanjian kerja, pemutusan hubungan kerja dan meninggal dunia kecuali yang mengundurkan diri ditanggung oleh pelaut perikanan. Keempat, penyelesaian perselihan antara pengguna dan pelaut secara musyawarah, mediasi dan/atau jalur hukum. Kelima, PPTKIS (Pelaksana Penempatan Tenaga Kerja Indonesia Swasta) wajib melaporkan kedatangan pelaut perikanan kepada perwakilan Republik Indonesia.

\section{Peraturan Kepala Badan Nasional Penempatan dan Perlindungan Tenaga} Kerja Indonesia Nomor : PER.12/KA/IV/2013 tentang Tata Cara Perekrutan Penempatan dan Perlindungan Pelaut di Kapal Berbendera Asing

Perlindungan pelaut juga secara langsung diatur pada Bab IV yang mewajibkan setiap pelaut memiliki dokumen, kurang lebih sama halnya dengan ketentuan huruf H dalam Perka Nomor 3 Tahun 2013 kecuali, kartu identitas pelaut (Seafarer Identity Document/SID) bagi negara yang mewajibkan; Pemilik kapal wajib mengansuransikan pelaut di luar negeri dan menanggung biaya premi asuransi dan apabila terjadi kerugian finansial yang dialami pelaut maka P5 (Perusahaan Pelaksana Perekrutan dan Penempatan Pelaut) wajib untuk memberikan kompensasi sebagaimana tercantum dalam PKL.

Perlindungan yang diberikan juga meliputi penyelesaian perselisihan antara pemilik kapal dan pelaut secara musyawarah, Tripartit, pengadilan hubungan industrial, dan diselesaikan sesuai ketentuan hukum yang berlaku; apabila terjadi pemutusan hubungan kerja maka, pelaut berhak atas pesangon dan biaya pemulangan kecuali mengundurkan diri; pelaut berhak atas biaya perawatan dan pengobatan; dan pemulangan pelaut. 


\section{Perlindungan Pelaut menurut Maritime Labour Convention 2006}

Sebelum membahas tentang pengaturan perlindungan hak pelaut berdasarkan MLC, perlu diketahui bagian-bagian MLC 2006. Pengaturan dalam MLC terdiri dari 5 bab yaitu:

Bab 1 : Syarat minimum bagi para pelaut untuk bekerja di kapal (minimum requirements for seafarer to work on a ship).

Bab 2 : Kondisi kerja (condition of employment).

Bab 3 : Akomodasi, fasilitas-fasilitas rekreasi, makanan dan katering (accommodation, recreational facilities, food and catering).

Bab 4 : Perlindungan kesehatan, perawatan medis, perlindungan keamanan dan kesejahteraan sosial (health protection, medical care, welfare and social security protection)

Bab 5 : Penerapan dan penegakkan hukum (compliance and enforcement)

Konvensi ini terdiri dari 3 bagian yaitu Articles, Regulations dan Code. Articles dan Regulations menetapkan hak-hak dan prinsip-prinsip dasar dan kewajiban-kewajiban dasar negara anggota ILO yang telah meratifikasi MLC 2006. Sedangkan, Code memuat rincian bagi penerapan peraturan. Perlu dipahami bahwa MLC bersifat wajib ditaati/ mandatory dan tidak wajib/ non-mandatory, kedua hal tersebut dimuat dalam Code bagian A dan B. Code A, memuat ketentuan yang bersifat wajib ditaati dan diterapkan oleh negara anggota dan B berisikan petunjuk atau sebuah pedoman yang sifatnya rekomendasi dan atau tidak wajib untuk diterapkan oleh negara yang meratifikasi Konvensi. ${ }^{10}$ Regulations dan Code terdiri dari 5 bab yang berisi ketentuan-ketentuan yang telah disebutkan oleh Penulis sebelumnya.

\section{Analisa Perlindungan Pelaut menurut Peraturan Perundang-Undangan Sebelum Ratifikasi MLC 2006 dan menurut MLC 2006}

\section{Usia Minimum}

Pada Pasal 17 PP Kepelautan mensyaratkan pekerja pelaut berusia sekurang-

\footnotetext{
${ }^{10}$ Penjelasan Undang-Undang Republik Indonesia Nomor 15 Tahun 2016 tentang Pengesahan Maritime Labour Convention, 2006.[5]..
} 
kurangnya 18 tahun, atau disebut pelaut magang. Sedangkan, MLC2006 mensyaratkan pekerja sebagai pelaut muda berusia antara $16-18$ tahun. Sehingga, pekerja pelaut muda yang semestinya diberikan perlindungan berdasarkan ketentuan MLC 2006. Oleh karena berlaku Undang-Undang Nomor 15 Tahun 2006 tentang pengesahan MLC, pekerja pelaut dibawah umur mendapatkan perlindungan seperti hak atas jam kerja maksimal dan waktu istirahat sebagaimana diatur dalam konvensi. Pada PP Kepelautan mengatur maksimal jam kerja pelaut muda adalah 8 jam, sedangkan MLC 2006 pada Regulation 1.1 Standard A.1.1 Pasal 2, maksimal jam kerja pelaut muda adalah 9 jam. Dengan demikian, setelah diratifikasinya MLC 2006 para pelaut muda akan bekerja 1 jam lebih lama. Pada PP Kepelautan dan MLC mengatur hal yang sama, bahwa pelaut muda yang berumur 16 - 18 tahun dipekerjakan sebagai apapun tetapi tidak diperbolehkan untuk bekerja lebih dari 8 jam kerja sehari dan 40 jam seminggu dan pada waktu istirahat kecuali dalam keadaan darurat.

Pada MLC 2006, mengatur tentang pembatasan jam kerja lebih spesifik dari peraturan perundang-undangan yang ada. MLC 2006 menyebutkan bahwa setiap pelaut muda yang berumur 16 - 18 tahun dilarang dipekerjakan pada waktu tengah malam dan sebelum jam 5 pagi. Peran hukum nasional wajib mendefinisikan waktu tengah malam pada setiap negara anggota. Dalam Undang-Undang Ketenagakerjaan hanya mendefinisikan waktu siang. Oleh karena itu, perlu dilakukan penafsiran hukum yaitu penafsiran sistematis. Penafsiran sistematis, yaitu menafsirkan beberapa ketentuan hukum yang mengatur tentang hal yang sama. ${ }^{11}$ Pada Pasal 1 angka 27 Undang-Undang Ketenagakerjaan menyebutkan bahwa siang hari adalah waktu antara pukul 06.00 sampai dengan pukul 18.00. Sebagai suatu penyelesaian, dapat dilakukan penafsiran berlawanan atau disebut juga dengan argumentum a contrario. Apabila Undang-Undang Ketenagakerjaan mendefinisikan siang hari pukul 06.00 hingga 18.00 maka, malam adalah diluar jam tersebut. Sehingga, malam adalah di atas pukul 18.00 - 05.00. Maka, mengacu pada ketentuan UndangUndang Ketenagakerjaan dan MLC 2006 terhadap jam kerja pelaut muda dilarang

${ }^{11}$ Asri Wijayanti dan Lilik Sofyan Achmad, Strategi Penulisan Hukum, Lubuk Agung, Bandung, 2011.[27]. 
untuk dipekerjakan di atas pukul 18.00 hingga 05.00 kecuali dalam keadaan darurat atau kegiatan tertentu.

\section{Kualifikasi Pelatihan}

MLC 2006 tidak mengatur standar terhadap pelatihan pelaut, tetapi pada setiap negara anggota MLC 2006 harus memiliki standar pelatihan masingmasing. Jenis dan bentuk pelatihan wajib ditentukan hukum nasional sesuai dengan kebutuhan negara. Dalam Handbook Guidance on Implementing the Maritime Labour Convention 2006 pada intinya menjelaskan bahwa MLC mengerti apabila setiap negara dianggap paling tahu terkait teritorial dan sumber daya manusia yang ada dan kebutuhan pelaut saat berlayar, sehingga pengelolaan pelatihan pelaut adalah kewenangan negara anggota. ${ }^{12}$ Ketentuan standar pelatihan setiap negara wajib mengatur standar keamanan kerja dan bagi pelaut yang telah terlatih wajib menunjukkan sertifikasi oleh pihak yang berwenang dan sesuai dengan jabatan pelaut dalam konvensi SCTW sebagai tolak ukur.

Saat ini pendidikan dan pelatihan pelaut diatur berdasarkan Peraturan Menteri Perhubungan Nomor 70 Tahun 2013 tentang Pendidikan dan Pelatihan Sertifikasi serta Dinas Jaga Pelaut. Dalam peraturan ini sertifikasi atas pelatihan diberikan kepada pelaut dengan jabatan:

1. Sertifikat Keahlian Pelaut Nautika;

2. Sertifikat Rating Dinas Jaga Navigasi dan Kemudi;

3. Sertifikat Pelaut Terampil bagian Dek;

4. Sertifikat Keahlian Pelaut Teknik Permesinan;

5. Sertifikat Rating Dinas Jaga Mesin;

6. Sertifikat Electro-Technical Officer;

7. Sertifikat Rating Teknik Elektro;

8. Sertifikat Keahlian Pelaut Operator Radio;

9. Sertifikat Nahkoda, Perwira, dan Rating Pada Kapal Tangki Gas Cair; dan

10. Sertifikat Nahkoda, Perwira, dan Rating Pada Kapal Penumpang.

\footnotetext{
${ }^{12}$ International Labour Organization, Handbook Guidance on implementing the Maritime Labour Convention, 2006 Model National Provisions, Geneva, 2012..[40].
} 


\section{Perjanjian Kerja Pelaut}

Pasal 18 ayat (3) PP Kepelautan mengatur lebih spesifik dibanding MLC 2006 yang memuat sedikitnya identitas pelaut, jumlah upah, pemutusan perjanjian, manfaat perlindungan jaminan kesehatan dan sosial, hak pemulangan, dan rujukan untuk perjanjian kerja. Pada PP Kepelautan, dalam perjanjian kerja sekurangkurang harus memuat apa saja hak-hak pelaut dan kewajiban pelaut termasuk hak pemilik dan kewajiban pemilik.

\section{Upah}

MLC 2006 tidak mengatur secara spesifik pula mengenai rumusan perhitungan upah pelaut, tetapi setiap negara anggota wajib untuk menyediakan metode perhitungan pembayaran upah pelaut yang dibayar tidak boleh lebih lama dari satu bulan. Berbeda dengan PP Kepelautan Pasal 22 ayat (2) yang menyatakan bahwa upah lembur per jam dihitung dengan rumus upah minimum/190 x 1,25. Berdasarkan penjelasan dari PP tersebut, penetapan angka 190 adalah jumlah jam kerja dalam 1 (satu) bulan. Sedangkan penetapan angka 1,25 adalah sesuai ketentuan Konvensi ILO. Lebih lanjut, rumusan untuk hari libur pelaut akan dibayar dihitung untuk setiap bulan 4 (empat) hari kerja, yang besarnya setiap hari 1/30 (sepertigapuluh) dari gaji minimum bulan.

\section{Jam Kerja dan Jam Istirahat}

Pada Pasal 21 ayat (1) PP Kepelautan mengatur secara khusus tentang jam kerja pelaut yang ditetapkan 8 (delapan) jam setiap hari dengan 1 (satu) hari libur setiap minggu dan hari libur resmi. Apabila jam kerja melebihan ketentuan maka dihitung lembur. Sedangkan, jam istirahat menurut ayat (4) dalam PP ini menyatakan setiap pelaut harus diberikan jam istirahat paling sedikit 10 (sepuluh) jam dalam jangka waktu 24 (dua puluh empat) jam yang dapat dibagi 2 (dua), salah satu diantaranya tidak boleh kurang dari 6 (enam) jam kecuali dalam tugas darurat.

Menurut MLC 2006 berdasarkan Regulation 2.3 dalam Pasal 5 ditentukan maksimal waktu kerja pelaut, bahwa jam kerja pelaut tidak lebih dari 14 jam untuk 
periode 24 jam dan 72 jam untuk periode seminggu atau minimum waktu istirahat tidak kurang dari 10 jam dalam periode 24 jam dan 77 jam dalam periode seminggu.

Dalam hal ini, ketentuan jam kerja dalam MLC 2006 mengatur jam kerja yang lebih tinggi yaitu 14 jam dibanding jam kerja dalam PP Kepelautan. Pengaturan ini dapat dijadikan sebagai tolak ukur maksimum jam kerja.

\section{Hak Cuti}

Pada Pasal 24 ayat (1) PP Kepelautan menyatakan bahwa setiap pelaut mendapatkan cuti tahunan paling lama 20 hari kalender untuk setiap jangka waktu 1 tahun bekerja. Dalam PP ini, atas permintaan pengusaha, tidak melarang pelaut untuk mengganti hak cutinya dengan imbalan sejumlah hari cuti. Dalam MLC 2006, Regulation 2.4 Pasal 2 menyatakan bahwa cuti minimal dihitung atas dasar 2,5 hari kalender per bulan kerja. Maka dalam 1 tahun, pelaut memiliki hak cuti selama 2,5 hari $\mathrm{x} 12$ bulan $=30$ hari cuti, dengan syarat cuti tidak termasuk absen.

Ketentuan MLC 2006 memberikan waktu cuti yang lebih lama kepada pelaut dibanding PP Kepelautan. Akan tetapi, MLC 2006 melarang adanya penggantian hari cuti dengan imbalan kecuali ketentuan tertentu yang diatur lebih lanjut oleh pihak berwenang, naka diperbolehkan.

\section{Standar Pengawakan Kapal}

Menurut Guide Book MLC 2006, setiap pelaut dianggap layak dalam mengawaki kapal harus memiliki Safe Manning Document (SMD) ${ }^{13}$ sebagai bukti. Oleh karena itu, MLC 2006 memberikan hak kepada negara anggota masing-masing untuk mengatur ketentuan tentang pengawakan sepanjang tidak melanggar ketentuan jam kerja, jam istiraat dan jenis jabatan pekerja. Berdasakan Undang-Undang Pelayaran Pasal 338 menyebutkan ketentuan mengenai pendidikan dan pelatihan sumber daya

13 Berdasarkan PM 70 Tahun 2013, Sertifikat Pengawakan atau Safe Manning Document (SMD) adalah sertifikat yang dikeluarkan oleh Direktorat Jenderal Perhubungan Laut untuk pelaut yang memenuhi persyaratan kualifikasi dan kompetensi sesuai dengan ketentuan nasional dan internasional yang menerangkan jumlah pelaut yang diwajibkan dan sertifikat keahlian. 
manusia sebagaimana dimaksud dalam Pasal 263 dan 264 yang berlaku secara mutatis mutandis untuk bidang transportasi. Maka, Kementerian Perhubungan berhak untuk mengatur SMD yang merupakan salah satu prasyarat pelaut.

\section{Akomodasi dan Fasilitas Rekreasi}

Akomodasi merupakan akomodasi ruangan dan pelayanan lainnya yang diberikan kepada pelaut yang bekerja di kapal berbendera. Dengan diratifikasinya MLC pemilik kapal berkewajiban untuk menyediakan ruangan laundry, ruang komunal pekerja, ruang kantor, mosquito infested port, akomodasi ruang sosial serta melakukan inspeksi kapal internal secara rutin untuk menjaga kebersihan, keselamatan dan keamanan akomodasi yang ada. Berbeda dengan Peraturan Pemerintah Nomor 7 Tahun 2000 yang hanya menyediakan ruang tidur, ruang santai, ruang makan dan pantry, ruang sanitasi dan ruang kesehatan.

\section{Makanan dan Katering Pelaut}

Pada PP Kepelautan mengatur bahwa pengusaha kapal wajib menyediakan makanan dan alat-alat pelayanan makanan yang cukup dan layak bagi setiap pelayaran. Makanan harus memenuhi jumlah, ragam dan nilai gizi dengan minimum 3600 kalori per hari.

Sedangkan, MLC 2006 mengatur lebih spesifik dengan menjamin hak atas kehidupan yang layak bagi pelaut. Makanan harus bervariasi, bernutrisi dan higienis, serta wajib dikelola oleh staf katering dan koki pelat terlatih yang memiliki keahlian dalam memasak makanan praktis, menjaga kebersihan pribadi, memiliki kemampuan mengelola stok makanan dan bertanggung jawab atas perlindungan lingkungan, kesehatan dan keamanan katering. Kemudian, Port State Control wajib untuk mengecek persediaan makanan dan minuman kapal sebelum berlayar, mengecek ruangan dan alat makan layak pakai, termasuk keadaan dapur dan peralatan dalam pelayanan makanan. MLC 2006 juga memberlakukan larangan bagi koki pelaut muda di bawah 18 tahun, untuk mencegah kelalaian terhadap pelaut yang belum berpengalaman. 


\section{Perawatan Medis saat Kapal Berlayar dan Mendarat}

Pada Undang-Undang Pelayaran Pasal 152 ayat (1) menyatakan bahwa setiap kapal yang mengangkut penumpang wajib menyediakan fasilitas bagi penumpang. Lebih lanjut ayat (2) menjelaskan bahwa fasilitas kesehatan meliputi ruang pengobatan, peralatan medis dan obat-obatan dan tenaga medis. Pada MLC 2006, memperluas penyediaan jasa medis dan akses obat-obatan tidak terbatas hanya pada kapal penumpang, tetapi mencakup terhadap segala jenis kapal.

Lebih lanjut, dalam PP Kelautan menyatakan bahwa setiap kapal dengan jumlah 15 pelaut atau lebih harus dilengkapi dengan ruang perawatan kesehatan yang layak dan memiliki kamar mandi dan jamban sendiri. Untuk pemberian pelayanan kesehatan di kapal, nahkoda dapat meminta bantuan nasehat dari tenaga medis di darat dengan media radio dalam keadaan tertentu.

Pada MLC 2006 mewajibkan bagi kapal yang membawa 100 penumpang atau lebih dan melakukan perjalanan internasional dan lebih dari 3 hari wajib memiliki dokter yang berkualitas dan bertanggung jawab untuk menyediakan perawatan medis, hal ini untuk mencegah apabila terdapat penumpang atau pelaut yang sakit dan sulit terhadap akses daratan karena waktu perjalanan yang lama. Sedangkan, bagi kapal yang mengangkut di bawah 100 penumpang dan perjalanan tergolong singkat dapat meminta bantuan dari pelaut yang bersertifikasi medis sesuai ketentuan $S T C W$ untuk berjaga-jaga di atas kapal. MLC 2006 juga mewajibkan adanya sistem komunikasi melalui radio atau satelit untuk berkomunikasi di dalam kapal apabila terdapat pasien yang sakit, komunikasi disambungkan ke daratan terdekat dengan tujuan untuk memberikan saran dari para ahli spesialis terhadap penanganan pasien dan jika memungkinkan tersedia dalam 24 jam dan biaya ringan. Dengan demikian, ketentuan dalam MLC 2006 sangat menjamin kesehatan dan keselamatan pelaut saat sakit.

\section{Perlindungan Kesehatan dan Keamanan dan Perlindungan terhadap Kecelakaan}

Pada Undang-Undang Pelayaran Pasal 79 dan 80, dalam ayat (1) disebutkan kegiatan keselamatan dan keamanan pelayaran dilakukan secara terpadu dalam 
rangka pengawasan kelaiklautan kapal, tertib lalu lintas, dan lain-lain serta penegakan hukum yang berkoordinasi antara Port State Control dengan pengusaha kapal. Keselamatan dan keamanan pelayaran meliputi keselamatan dan keamanan angkutan di perairan, pelabuhan, serta perlindungan lingkungan maritim. ${ }^{14}$

Pada MLC 2006, mengatur peran yang lebih besar dan spesifik bagi Port State Control. Dalam hal ini, Port State Control harus melakukan meningkatkan kemampuan secara aktif terhadap keamanan dan keselamatan kerja di atas kapal serta melakukan evaluasi resiko terhadap pekerjaan di atas kapal. Port State Control juga melakukan inspeksi berkala, selain hanya melakukan investigasi juga berperan aktif untuk menganalisa statistik kecelakaan, aktif menerima keluhan dan pelaporan terhadap pelanggaran hukum di atas kapal atau pelanggaran hak pelaut oleh pemberi kerja dan melakukan riset terhadap peristiwa kapal dan pelaut yang sering terjadi.

Inspeksi dilakukan oleh inspektur yang diberikan mandat dan memiliki wewenang untuk menaiki kapal yang terdaftar di wilayah negara anggota dan memasuki tempat yang perlu diinvestigasi. Kemudian, inspektur melakukan pemeriksaan, pengujian dan meminta keterangan penting untuk memuaskan diri mereka bahwa ketentuan hukum yang berlaku masih diawasi dengan ketat. Apabila terdapat kecacatan, maka diminta untuk diperbaiki. Bilamana kecacatan tersebut dapat membahayakan kesehatan dan keselamatan pelaut, secara administratif inspektur dapat melarang kapal agar tidak meninggalkan pelabuhan sampai dilakukan tindakan yang diperlukan. ${ }^{15}$

\section{Kesimpulan}

Pengaturan nasional tentang hak-hak dasar pelaut meliputi UU Pelayaran, PP Kepelautan, Permenhub Nomor 84 Tahun 2003, Peraturan Kepala BNP2TKI Nomor PER-03/KA/I/2013, Peraturan Kepala BNP2TKI Nomor PER-12/KA/ IV/2013 dan UU Nomor 15 Tahun 2016. Sebagian besar hak-hak dasar pelaut yang dijelaskan dalam peraturan nasional tersebut mencakup hak-hak yang harus dimuat

\footnotetext{
${ }^{14}$ Pasal 116 ayat (1) Undang-Undang Nomor 17 Tahun 2008 tentang Pelayaran.

15 Labour Inspection (Seafarers) Convention, 1966 (No. 178), art. 5.
} 
dalam perjanjian kerja laut (misalnya gaji, jam kerja dan jam istirahat, pemulangan, dll) dan hak-hak lainnya di luar perjanjian kerja. Pada pengaturan internasional, MLC 2006, hak-hak dasar yang dimiliki pelaut dalam konvensi ini, diatur dalam ketentuan Pasal 3 dan Pasal 4.

Pada kerangka hukum nasional diatur tentang perlindungan pelaut dalam UU Pelayaran, PP Kepelautan, UU TPPO, PP Angkutan di Perairan, Permenhub Nomor 84 Tahun 2013, SE Dirjen Hubla Nomor UK11/21/12/DJPL-06, Permen KKP Nomor 35/Permen-KP/2015, Peraturan Kepala BNP2TKI Nomor PER.13/KA/VII/2009, Peraturan Kepala BNP2TKI Nomor PER.03/KA/I/2013, Peraturan Keala BNP2TKI Nomor PER.12/KA/IV/2013. Perlunya konvensi MLC 2006 yang telah diratifikasi Indonesia melalui UU Nomor 15 Tahun 2016 untuk lebih menjamin perlindungan pelaut Indonesia dengan memberikan standar pedoman yang berlaku secara internasional bagi negara dan pemilik kapal. MLC 2006 memuat 5 bab pokok yaitu syarat minimum bagi para pelaut untuk bekerja di kapal; kondisi kerja; akomodasi, fasilitas-fasilitas rekreasi, makanan dan katering; perlindungan kesehatan, perawatan medis, perlindungan keamanan dan kesejahteraan sosial; penerapan dan penegakkan hukum. Apabila dibandingkan dengan melihat ketentuan Pasal dalam perundanganundangan nasional dan MLC 2006, konvensi ini dinilai lebih spesifik dan fleksibel dalam mengatur hal yang sama dengan ketentuan nasional.

\section{Daftar Bacaan}

\section{Buku}

Asri Wijayanti dan Lilik Sofyan Achmad, Strategi Penulisan Hukum (Lubuk Agung 2000).

International Labour Organization, Handbook Guidance on implementing the Maritime Labour Convention 2006 Model National Provisions (2012).

Paul SinlaEloe, Tindak Pidana Perdagangan Orang (Setara Press Malang, 2017).

\section{Jurnal}

Pusat P2K OI - BPPK Kementerian Luar Negeri Republik Indonesia, Strategi Perlindungan dan Penanganan Kasus Anak Buah Kapal (SEAFARER) Sektor 
Perikanan Indonesia yang Bekerja di Luar Negeri, hasil penelitian.

Sukmawati Mustari, Hak Atas Pekerjaan Dengan Upah Yang Seimbang, Supremasi Jurnal Fakultas Ilmu Sosial Universitas Negeri Makassar, Vol. XI, No. 2, 2016.

\section{Laman/Media Online}

Tak Pernah Berhenti Perjuangkan Nasib Pelaut, PPI Rilis Catatan Akhir Tahun 2017, http://www.maritimenews.com

\section{Perundang-undangan}

Undang-Undang Dasar Negara Republik Indonesia Tahun 1945.

Undang-Undang Republik Indonesia Nomor 21 Tahun 2007 tentang Pemberantasan Tindak Pidana Perdagangan Orang, Lembaran Negara Republik Indonesia Tahun 2007 Nomor 58, Tambahan Lembaran Negara Republik Indonesia Nomor 4720.

Undang-Undang Republik Indonesia Nomor 17 Tahun 2008 tentang Pelayaran, Lembaran Negara Republik Indonesia Tahun 2008 Nomor 64, Tambahan Lembaran Negara Republik Indonesia Nomor 4849.

Undang-Undang Republik Indonesia Nomor 15 Tahun 2016 tentang Pengesahan Maritime Labour Convention, 2006 (Konvensi Ketenagakerjaan Maritim), Lembaran Negara Republik Indonesia Tahun 2016 Nomor 193, Tambahan Lembaran Negara Republik Indonesia Nomor 5931.

Undang-Undang Republik Indonesia Nomor 18 Tahun 2017 tentang Perlindungan Pekerja Migran Indonesia, Lembaran Negara Republik Indonesia Tahun 2017 Nomor 242, Tambahan Lembaran Negara Republik Indonesia Nomor 6141.

Peraturan Pemerintah Nomor 7 Tahun 2000 tentang Kepelautan, Lembaran Negara Republik Indonesia Tahun 2000 Nomor 13, Tambahan Lembaran Negara Republik Indonesia Nomor 3929.

Peraturan Pemerintah Nomor 20 Tahun 2010 tentang Angkutan di Perairan, Lembaran Negara Republik Indonesia Tahun 2010 Nomor 26, Tambahan Lembaran Negara Republik Indonesia Nomor 5108.

Peraturan Menteri Perhubungan Nomor 84 Tahun 2013 tentang Perekrutan dan Penempatan Awak Kapal.

Peraturan Menteri Perhubungan Nomor 70 Tahun 2013 tentang Pendidikan dan 
Pelatihan, Sertifikasi serta Dinas Jaga Pelaut.

Peraturan Menteri Kelautan dan Perikanan Nomor 35/PERMEN-KP/2015 tentang Sistem dan Sertifikasi Hak Asasi Manusia Pada Usaha Perikanan.

Peraturan Kepala Badan Nasional Penempatan dan Perlindungan Tenaga Kerja Indonesia Nomor PER.13/KA/VII/2009 tentang Pendataan Pelaksana Penempatan Pelaut Indonesia di Luar Negeri.

Peraturan Kepala Badan Nasional Penempatan dan Perlindungan Tenaga Kerja Indonesia Nomor PER.03/KA/I/2013 tentang Tata Cara Penempatan dan Perlindungan Tenaga Kerja Indonesia Pelaut Perikanan di Kapal Berbendera Asing.

Peraturan Kepala Badan Nasional Penempatan dan Perlindungan Tenaga Kerja Indonesia Nomor PER.12/KA/IV/2013 tentang Tata Cara Perekrutan, Penempatan dan Perlindungan Pelaut di Kapal Berbendera Asing.

Keputusan Menteri Perhubungan Nomor 70 Tahun 1998 tentang Pengawakan Kapal Niaga.

Konvensi ILO Nomor 29/1930 tentang Kerja Paksa.

The International Convention for the Safety of Life at Sea (SOLAS), 1974.

The International Convention for the Prevention of Pollution from Ships (MARPOL).

The International Convention on Standards of Training, Certification and Watchkeeping for Seafarers (STCW).

Labour Inspection (Seafarers) Convention, 1966.

Maritime Labour Convention, 2006.

HOW TO CITE: Nina Farah Adela, 'Perlindungan Pelaut Indonesia Di Luar Negeri Melalui Ratifikasi Maritime Labour Convention, 2006' (2018) Vol. 1 No. 2 Jurist-Diction. 